\title{
El Niño induced changes to the Bolivar Channel ecosystem (Galapagos): comparing model simulations with historical biomass time series
}

\author{
Matthias Wolff ${ }^{1,2, *}$, Diego J. Ruiz ${ }^{1,2}$, Marc Taylor ${ }^{3}$ \\ ${ }^{1}$ Charles Darwin Foundation, Santa Cruz, Galápagos, PO Box 17-1-3891 Quito, Ecuador \\ ${ }^{2}$ Leibniz Centre for Tropical Marine Ecology (ZMT) GmbH, Fahrenheitstrasse 6, 28359 Bremen, Germany \\ ${ }^{3}$ Alfred Wegener Institute for Marine and Polar Research, PO Box 120161, 27515 Bremerhaven, Germany
}

\begin{abstract}
During a strong El Niño event, nutrient and phytoplankton concentrations around the Galapagos archipelago greatly decrease, while sea surface temperature increases $\left(>7^{\circ} \mathrm{C}\right)$. Several species suffer under these conditions, while some benefit and new species appear. To understand the mechanisms behind observed changes, a trophic reference model of the Bolivar Channel ecosystem was forced by a 16 yr (1994 to 2009) satellite-derived time series of phytoplankton biomass including the El Niño period 1997/98. Emergent changes in model compartment biomasses, as derived from dynamic simulations, were compared to in situ observations of the subtidal communities and marine vertebrates over the study period. Observed population reductions of seabirds (penguins and flightless cormorants) and of several fish groups were well predicted by the simulations, suggesting that bottom-up effects largely control the system during an El Niño event. Observational data also enabled modifying the reference model to an El Niño state model. In this El Niño model, ecosystem size (total energy throughput) was reduced by $70.1 \%$. Overall system characteristics show great similarities with other coastal upwelling systems of the Peruvian coast in that strong El Niño events cause disruptions to trophic flows and keep them at a low (but highly productive) development state.
\end{abstract}

KEY WORDS: Trophic modeling $\cdot$ El Niño $\cdot$ Bolivar Channel ecosystem $\cdot$ Galapagos $\cdot$ Ecopath with Ecosim Resale or republication not permitted without written consent of the publisher

\section{INTRODUCTION}

The present study aims to explore how the recurrent El Niño climate phenomenon in the southeast Pacific affects the Bolivar Channel ecosystem, a shallow water area of the Galapagos archipelago. While scattered observations point to dramatic impacts of El Niño on various biota of the system, the mechanisms leading to observed changes have remained speculative, and much of the information found is just anecdotal. Our study is based on a trophic system modeling approach and on data collected during several years of subtidal monitoring of the Charles Darwin Foundation (including the strong El Niño event
1997/98). Based on these data, a trophic mass balance model of the system was constructed for a holistic presentation of the food web and for the quantification of average flows (Ruiz \& Wolff 2011), which is used here as a basis for the construction of an El Niño state model and as a reference for simulating the effect of historical dynamics in primary productivity on model compartments. In comparing simulated and observed biomass trajectories of the different model groups, we aim to understand the trophic mechanisms behind the observed changes.

The Bolivar Channel ecosystem (Fig. 1) is located in the western part of the Galapagos archipelago and belongs to a biogeographic 'cold water sub region' of 


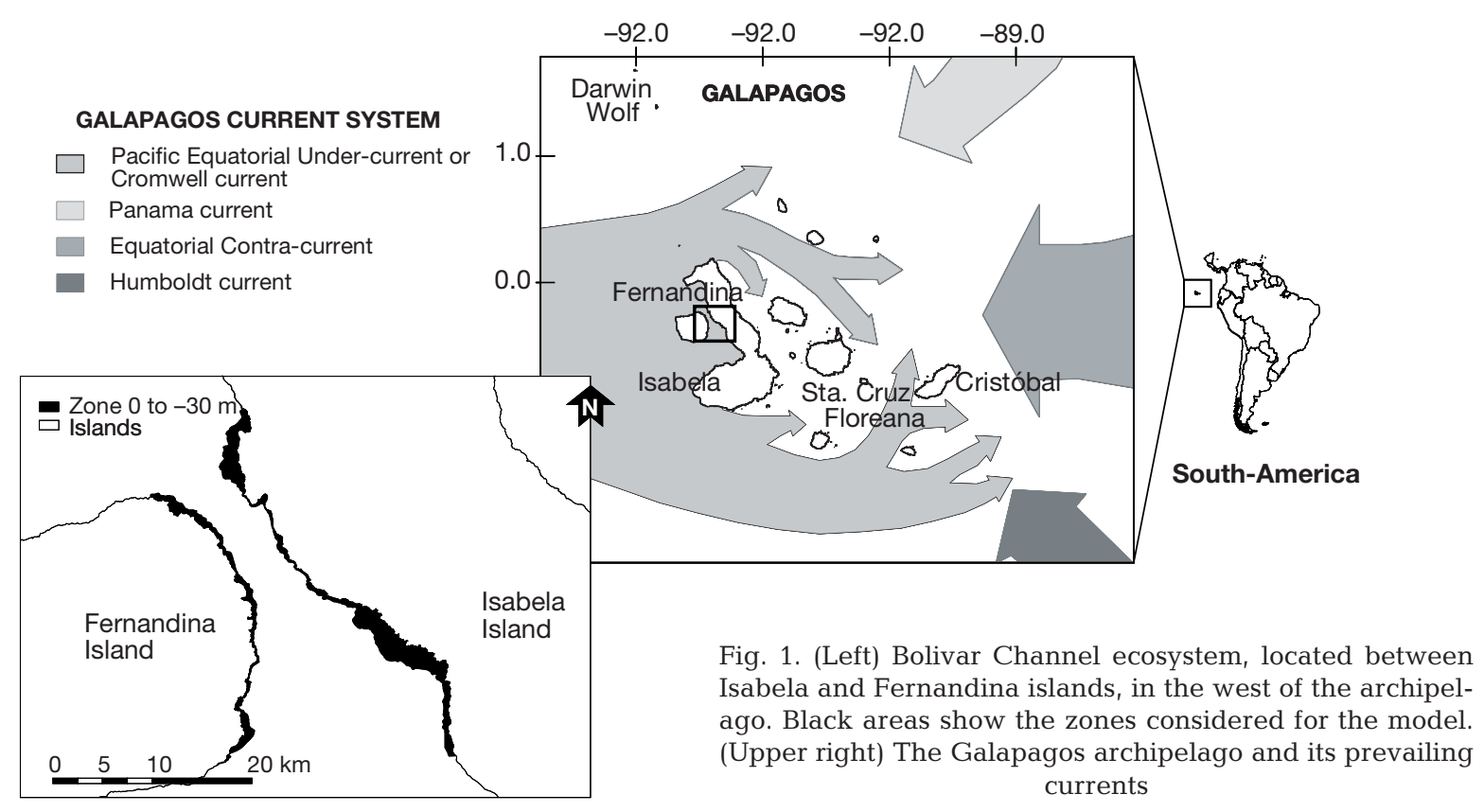

the archipelago, which is strongly shaped by the Pacific Equatorial Under-current (Cromwell current) that impinges on the archipelago from the west, frequently causing strong topographic upwelling of cold, nutrient-rich waters to the surface (Houvenaghel 1978, Eden \& Timmermann 2004). For this reason the mean sea surface temperature (SST) in this region is between 14 and $20^{\circ} \mathrm{C}$, generally lower than in the 'mixed water zone' around the central islands (18 to $24^{\circ} \mathrm{C}$ ) and much lower than in the northern warm zone around the islands of Wolf and Darwin (24 to $26^{\circ} \mathrm{C}$ ). The shallow habitats of the Bolivar Channel are heavily influenced by these cold, nutrient-rich upwelling waters. They are comprised mainly of rocky reef areas of bedrock, boulder, cobbles, and sand patches that spread along the coastline, interspersed by small sandy beaches and mangrove patches.

The system supports high resource biomasses of small pelagic fish such as sardines, thread-herrings, anchovies, pompano Trachinotus stilbe, and mackerel Scomberomorus sierra, which are in turn prey for substantial populations of top predators such as sharks Carcharinus galapagensis and Trianodon obesus, tuna Thunnus albacares, wahoo Acanthocybium solandri, barracuda Sphyraena idiastes, dolphin Tursiops truncates, seabirds Spheniscus mandicultus and Phalacrocorax harrisi, and marine pinnipeds Zalophus wollebaeki and Arctocephalus galapagensis (Feldman 1985, 1986), many of which actively visit the rocky reefs to feed.

This productive pelagic system surrounds and interfaces with the benthic rocky reef habitats of
Fernandina and Isabela Islands on the west and east sides of the Bolivar Channel, respectively. High production and accumulation of phytoplankton through the confluence of ocean currents, as well as dense macroalgae beds, provide elevated levels of primary production to these reefs. Many planktivorous fish that inhabit the rocky reef areas feed in the water column. The plankton also supports a high biomass of benthic filter-feeders that include gorgonians Muricea spp. and Pacifigorgia spp., zoanthids Parazoanthus spp., sponges Aplysilla sp. and Carmia sp., polychaetes Spirobranchus giganteus, and ahermatypic corals Tubastraea spp. In some parts of the Bolivar Channel macroalgae (Ulva sp., Sargassum sp., Spatoglossum sp., and Heterosiphonia sp.) form dense beds, while other areas are covered with filamentous algae, encrusting algae, and/or benthic diatoms. These primary producers are important food sources for several invertebrates, fish, and other vertebrates including marine iguanas Amblynchus cristatus. Two abundant species of sea urchins (Lytechinus semituberculatus, Eucidaris galapagensis) are the dominant herbivores on the benthic primary producers (Breen \& Mann 1976, Ayling 1981, Himmelman \& Lavergne 1985). Herbivore fish include damsels, sturgeon, and parrotfishes. Marine turtles Chelonea mydas are also present, and in some cases in high abundance. Several species of sea cucumbers (Holothura spp. and Isostichopus fuscus) are also highly abundant and make use of the rich detrital material in the area. Omnivorous reef fishes are 
mainly comprised of butterflies, damsels, and chopas, which consume both algae and small invertebrates. Grunts, wrasses, and angel fishes are the main invertebrate feeders, as are the carnivorous invertebrates, which include lobsters (Panulirus sp. and Scyllarides astroi), crabs, sea stars (Pentaceraster cumingi and Asteropsis carinifera), and gastropods (Pleuroploca princeps).

In the higher trophic levels we find piscivorous fishes such as the endemic grouper of Galapagos (Mycteroperca olfax) and snappers, octopuses Octopus spp., sea lions Zalophus wollebaeki, Galapagos penguin Spheniscus mandicultus, and flightless cormorant Phalacrocorax harrisi. Several sharks such as the Galapagos shark Carcharinus galapagensis and the white tip-reef shark Trianodon obesus also feed in these areas and interact with the pelagic system.

During the past $30 \mathrm{yr}$, the Galapagos archipelago, and particularly the zone of the Bolivar Channel, was greatly affected by both natural and anthropogenic impacts. Among the natural disturbances were the severe El Niño events 1982/83 and 1997/98, which brought extended periods (of about $8 \mathrm{mo}$ ) of unusually warm $\left(>26^{\circ} \mathrm{C}\right.$, occasionally up to $\left.29^{\circ} \mathrm{C}\right)$ and nutrient-depleted waters to the surface layer (Chavez et al. 1999, Enfield 2001, Glynn et al. 2001, Wellington et al. 2001), and phytoplankton biomass that was reduced by 50 to $70 \%$ of the mean quantity during periods of normal conditions (Kogelschatz et al. 1985, Jiménez 2008).

Monitoring surveys conducted by the Charles Darwin Foundation before, during, and after these warm El Niño periods revealed changes in the abundance of subtidal organisms and also showed that the emblematic penguin and flightless cormorant populations suffered greatly during the warming events. It was hypothesized that among the main causes for the changes in the bird population numbers were shortage of food (mainly small pelagic fish) resulting from the disruption of the trophic structure of the system through the bottom-up effect of reduced primary production (Vargas et al. 2006).

To elucidate the mechanisms behind the observed changes we explored the impact of El Niño 1997/98 on the system by forcing changes in primary producer biomass as derived from remote sensing (phytoplankton) and Charles Darwin Foundation surveys of macroalgae. The model response in terms of biomass changes of other model groups was then compared to functional group's biomass estimates as derived from subtidal ecological monitoring (SEM) and the marine vertebrate population monitoring (1994-2009) carried out by the foundation.

\section{MATERIALS AND METHODS}

\section{Comparing the reference model and the El Niño state model of the Bolivar Channel}

All modeling explorations were conducted with the software Ecopath with Ecosim ver. 6.0 (EwE) (Christensen et al. 2008). Biomass inputs for the 30 groups of the reference model (Ruiz \& Wolff 2011; Table S1 in the supplement at www.int-res.com/articles/suppl/ m448p007_supp.pdf) were based on mean compartment biomasses in the Bolivar Channel derived from surveys during the period 2004-2008. Production/ biomass ratios $(P / B)$, consumption/biomass ratios $(Q / B)$, catches $(C)$ (in case of a fisheries resource), and diets were derived from various data sources as described by Ruiz \& Wolff (2011).

In order to create an El Niño model, we adjusted each group's biomass data to values representative for the El Niño period in 1998. For some groups (macroalgae, herbivorous zooplankton, small herbivorous gastropods, gorgonians, anemones and zoanthids, lobsters, predatory zooplankton, and small predatory gastropods), biomass estimates were not available, and these values were left blank in the input matrix. Ecotrophic efficiencies (the fraction of total production that is consumed within the system) of these groups were fixed at 0.95 and the model computed the missing biomass values. Catch values were adjusted to the new biomass values maintaining the original catch to biomass ratio $(=0.3 \times P / B \times$ $B$ ). This ratio was based on the assumption that the stocks were moderately exploited (30\% of annual biomass production removed) (Ruiz \& Wolff 2011). The diet matrix of the reference model was modified in light of the fact that many groups are rather unselective, opportunistic feeders and that available food item proportions had changed due to the El Niñocaused changes in biomass of most groups. Following the method of Taylor et al. (2008a), we thus adjusted the diet proportions to reflect predatory groups' consumption habits as well as the available production of prey groups. Moreover, an increased base percentage of detritus feeding (10\%) was assumed for most benthic feeders, which is proximate to values given in Ortiz \& Wolff (2002) and Taylor et al. (2008b) for benthic compartments in a Chilean and Peruvian bay system, respectively. The $P / B$ and $Q / B$ values for the functional compartments were maintained due to lack of information about these values during El Niño.

Once the El Niño model was balanced through a manual process of adjusting some of the input para- 
meters, it was subjected to the Ecoranger resampling routine, which draws a set of random input variables from normal distributions for each basic parameter. All confidence intervals around the input parameters were fixed at $20 \%$, as was similarly done by AriasGonzález et al. (1997) and Taylor et al. (2008a). Resampling was performed until 10000 runs passed the selection criteria. The best run was chosen as that with the smallest sum of square residuals between the input parameters and the mean value of all successful runs (for more information, see Christensen et al. 2000). The resulting steady-state model inputs and outputs are shown in Table S1 in the supplement, and selected system summary statistics were calculated and compared with those of the reference model (Table 1).

For both system state models, trophic impacts were estimated for each pair of functional groups (prey and predators, interacting directly or not) by means of the net impact matrix (Libralato et al. 2006). The net impact of prey on predators is given by the difference between positive effects (quantified by the fraction of the prey in the diet of the predator) and negative effects (evaluated through the fraction of total consumption of prey used by the predator) (Ulanowicz \& Puccia 1990). The mixed trophic impact (MTI) was then estimated by the product of all the net impacts for all the possible pathway in the trophic web that link the functional prey and predator groups. Negative elements of the matrix MTI indicate a prevailing negative effect of the predator on the prey; analogously, positive elements of MTI indicate prevailing positive effects of the prey on the predator. Therefore, negative elements of MTI can be associated to prevailing top-down effects and positive ones to bottomup effects (Libralato et al. 2006).

To visualize the major differences in flow structure between both system states the Lindeman spine routine of EwE was used, which aggregates the entire system into discrete trophic levels (Lindeman 1942, Baird \& Ulanowicz 1993). This routine, based on an approach suggested by Ulanowicz \& Kay (1991), visualizes the biomass of each (aggregated) trophic level and allows showing all flows into and out of each trophic level.

\section{Time series analysis}

Ecosim, basic equations

In Ecosim, the biomass dynamics of all ecosystem components that occupy trophic levels above the primary producers are determined by the following equation:

$$
\frac{\partial B_{i}}{\partial t}=g_{i} \sum C_{k i}-\sum C_{j i}+I_{i}-\left(M_{i}+F_{i}+e_{i}\right) B_{i}
$$

where $\partial B_{i} / \partial t$ is the rate of change in biomass of group $i_{i} g$ is the growth efficiency (proportion of food intake

Table 1. Ecosystem indicators to compare differences between the reference state model (Ruiz \& Wolff 2011) and the El Niño 1997/98 state model

\begin{tabular}{|c|c|c|c|}
\hline \multirow{2}{*}{ Ecosystem indicator } & \multicolumn{2}{|c|}{ Value } & \multirow[b]{2}{*}{ Difference (\%) } \\
\hline & Reference state & El Niño (EN) & \\
\hline \multicolumn{4}{|l|}{ Trophic indicators } \\
\hline Total system throughput ( $\left.\mathrm{km}^{-2} \mathrm{yr}^{-1}\right)$ & 38694.98 & 11578.55 & -70.07 \\
\hline Total net primary production ( $\mathrm{t} \mathrm{km}^{-2} \mathrm{yr}^{-1}$ ) & 17101.49 & 4093.07 & -76.07 \\
\hline Total biomass (excluding detritus) $\left(\mathrm{t} \mathrm{km}^{-2} \mathrm{yr}^{-1}\right)$ & 1276.28 & 492.30 & -61.43 \\
\hline Mean transfer efficiency (\%) & 17.40 & 17.60 & 1.15 \\
\hline Connectance index & 0.17 & 0.18 & 9.05 \\
\hline \multicolumn{4}{|l|}{ Fishery indicators } \\
\hline Total catches $\left(\mathrm{t} \mathrm{km}^{-2} \mathrm{yr}^{-1}\right)$ & 54.30 & 23.99 & -55.82 \\
\hline Mean trophic level of the catch & 2.45 & 2.62 & 7.03 \\
\hline Gross efficiency (catch/net primary production, \%) & 0.30 & 0.60 & 100 \\
\hline Primary production required/catch (PPR/catch) & 53.89 & 47.80 & -11.30 \\
\hline \multicolumn{4}{|l|}{ Energy indicators } \\
\hline System primary production/respiration & 4.20 & 1.41 & -66.44 \\
\hline System primary production/biomass & 13.40 & 8.31 & -37.95 \\
\hline System biomass/throughput & 0.30 & 0.04 & -85.83 \\
\hline \multicolumn{4}{|l|}{ Network indicators } \\
\hline Finn's cycling index & 1.29 & 4.19 & 224.80 \\
\hline Relative ascendency & 37.40 & 24.50 & -34.49 \\
\hline
\end{tabular}


converted into production); $F$ is fishing mortality; $M$ is natural mortality rate (excluding predation); $e$ is emigration rate; $I$ is immigration rate; and the first sum represents the food consumed, over prey types $k$ of species $i$, and the second sum represents the losses due to predation summed over all predators $j$ of $i$. In our model, immigration and emigration were assumed to be equal and thus were not considered. In Ecosim, the biomass of component $i$ that is vulnerable to predation by component $j\left(V_{i j}\right)$ is a function of a vulnerability rate (v).

$$
\frac{\partial V_{i j}}{\partial t}=v\left(B_{i}-V_{i j}\right)-v V_{i j}-a_{i j} V_{i j} B_{i j}
$$

where $a_{i j}$ is the effective rate at which predator $j$ searches for prey $i$. The vulnerable biomass increases from exchange with a pool of invulnerable biomass, $v\left(B_{i}-V_{i j}\right)$, and decreases when prey return to the invulnerable condition $\left(v V_{i j}\right)$ or by predation $\left(a_{i j} V_{i j} B_{j}\right)$. When $v$ is small, the flows between predators and prey are controlled mostly by variations in prey biomass, i.e. control is bottom-up. When $v$ is large, these flows are controlled mostly by variations in predator biomass, i.e. control is top-down. We started the simulations using the default vulnerability value $(v=2.0)$ and then did a second run with the vulnerability search routine of the program to see if the fit could be improved. The resulting changes in the vulnerability values for the model groups were then explored in the light of possible control mechanisms operating in the system.

\section{Simulating ecosystem response to the El Niño caused reduction in primary production}

To force the model with changes in phytoplankton biomass, a phytoplankton biomass time series for the period 1994 to 2009 was derived by the following steps: (1) For the period September 1997 to December 2009 monthly satellite data of chl $a$ and sea surface temperatures (SST) were used to reconstruct the time series for the Bolivar Channel area. Chl a estimates are from the ESA Globcolour database (http:// hermes.acri.fr/), which use estimates from the SeaWiFS sensor before April 2002 and a merged product of SeaWiFS-, MODIS-, and MERIS-derived estimates thereafter. SST estimates come from the AHRSS Pathfinder product (level 3) (NOAA). Both time series were converted to annual means and a regression between both variables was computed. (2) For the years 1994, 1995, and 1996 (those with SST data but without available satellite data for $\mathrm{chl}$ a), the annual means of SST were used to calculate the corresponding chl a values. (3) The resulting time series of $\mathrm{chl} \mathrm{a}$ $\left(\mathrm{mg} \mathrm{m}^{-3}\right)$ for the period 1994 to 2009 was then converted to wet weight biomass using the following conversions: chl $a$-carbon (40:1) (Brush et al. 2002) and carbon-wet weight (1:14.25) (Brown et al. 1991). In addition, a uniform mixed layer depth of $20 \mathrm{~m}$ was assumed (de Boyer Montégut et al. 2004) to derive biomass values per square meter.

Macroalgae biomass was used as a second forcing variable. Its time series was based on biomass estimates obtained during the SEM carried out by the Charles Darwin Foundation in the archipelago between the years 1997 and 2009 (Banks et al. 2003, Edgar et al. 2004, Banks et al. 2006, Edgar et al. 2011).

With these 2 forcing variables, the model was run for the period of $16 \mathrm{yr}$ (1994 to 2009), and the resulting changes in compartment biomasses were compared to the biomass estimates of the subtidal monitoring surveys conducted by the Charles Darwin Foundation between 1994 and 2009 and to the population census data of penguins and flightless cormorants available from the foundation's database (Vargas et al. 2006). The performance of the simulation was evaluated by the sum of squared differences (SS) between the simulated and reference (log) biomass time series. The significance of improvements in SS (i.e. decrease) for individual functional groups was assessed by the correlation of observed vs. simulated time series of (log) biomass.

\section{RESULTS}

\section{Comparing system characteristics between 'normal' and El Niño states}

Fig. 2 shows the biomass change of the model compartments from the normal state to the El Niño year 1998. Most model groups (21 of 29) largely decreased in biomass, while some (sea cucumbers and others, sea stars and sea urchins, lobsters, benthic predatory fish, barracudas, groupers, rays, and sharks) increased. This increase was noticeable only for the group sea cucumbers and others, however. Besides the primary producers (phytoplankton and macroalgae), several groups decreased by over $50 \%$, including herbivorous zooplankton, mullets, small planktivorous reef fish, jacks and mackerels, predatory marine mammals, and seabirds. Fig. 3 (Lindeman spine) summarizes these differences in biomass and flows between trophic levels for both system states and shows the highest biomass reduction for 


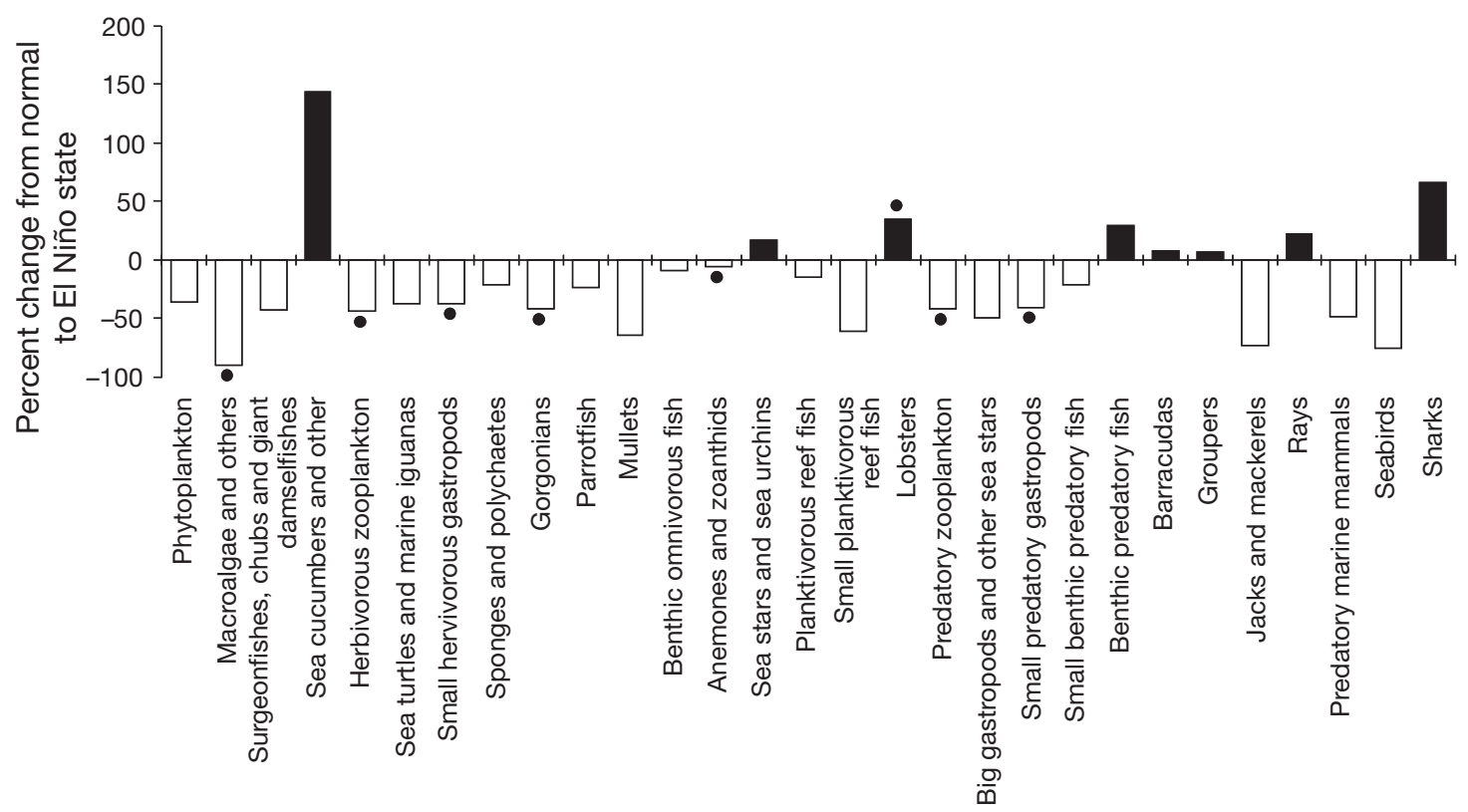

Functional compartments

Fig. 2. Biomass changes of model groups from normal to El Niño state (\%). Biomass for groups with black dots was estimated by the model during the balancing process

A

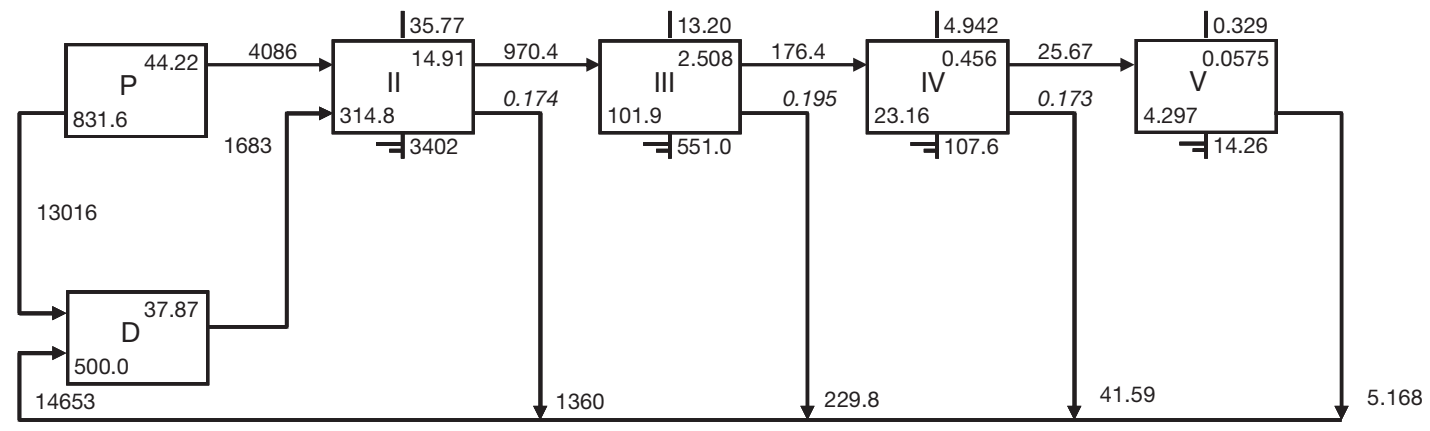

B
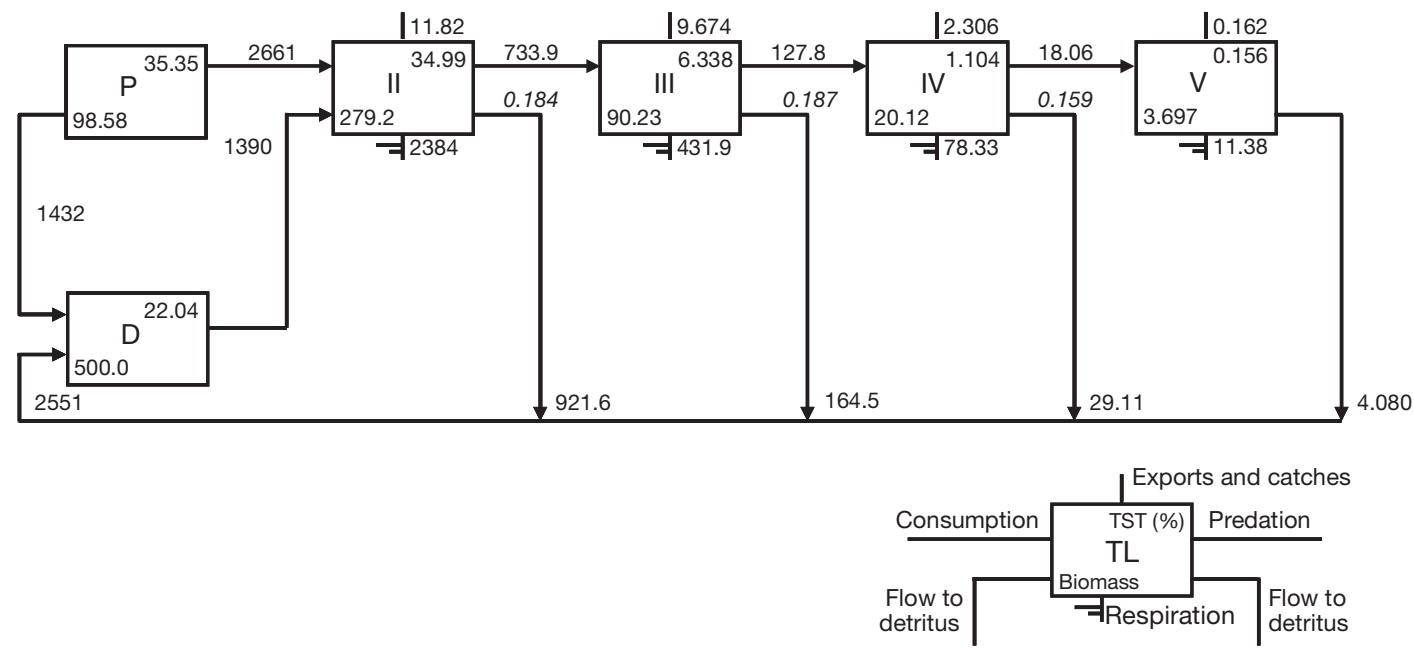

Fig. 3. Aggregated energy flow charts (Lindeman spine) (A) for reference model and (B) El Niño model of Bolivar Channel (only the first 5 trophic levels are considered, which comprise $>99.9 \%$ of total throughput). P: primary producers; D: detritus; see flowchart at lower right for description of numbers in boxes and on connecting lines 


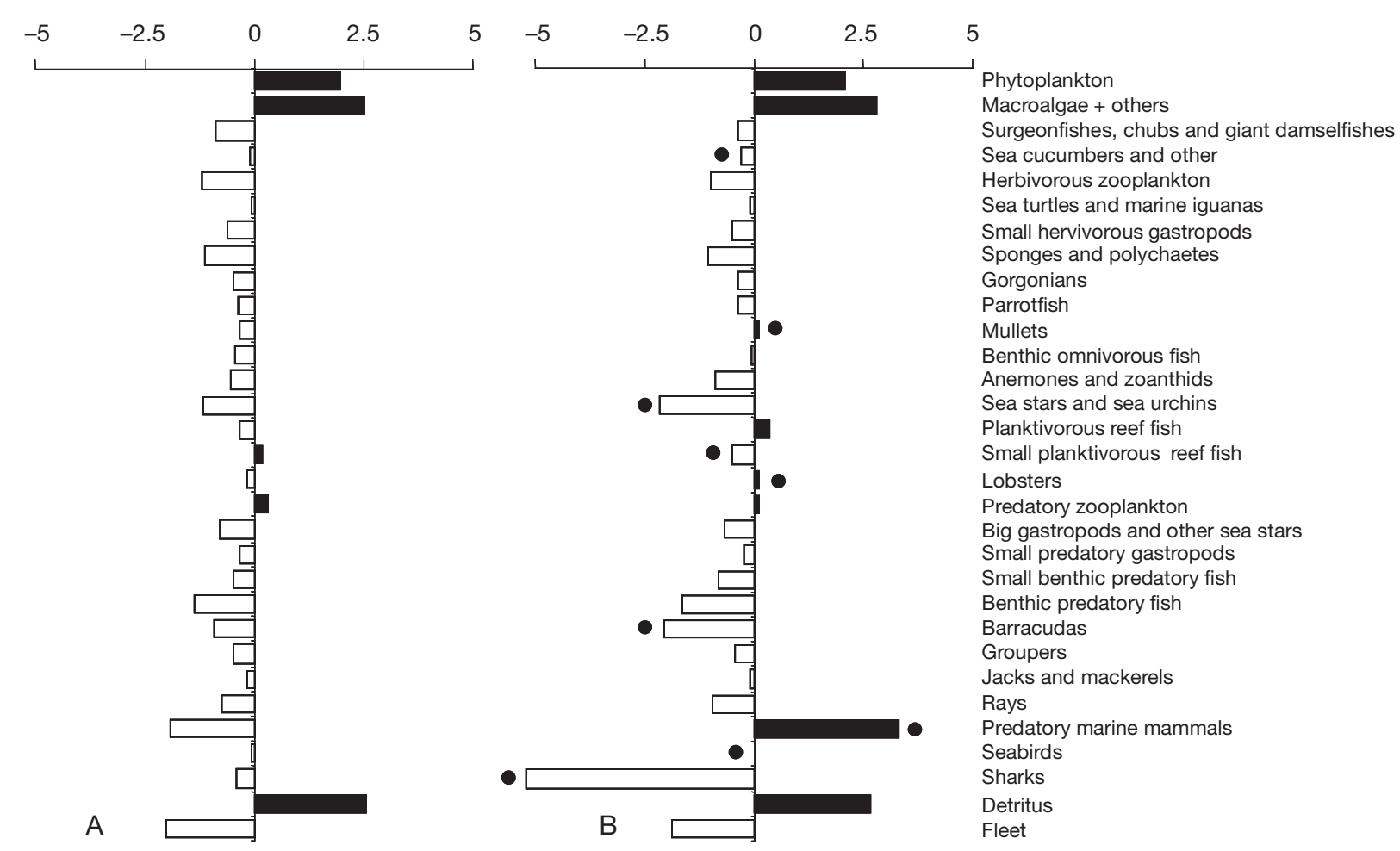

Fig. 4. Net impact analysis sensu Libralato et al. (2006) for (A) reference and (B) El Niño system states; positive impacts are indicated by the black bars, while the white bars show negative impacts (bars for groups with black dots show increase or decrease in impact strength by $>50 \%$ during the El Niño 1997/98 event)

the first trophic level (88.1\%). The decrease is lowest on the second and third level (11\%) and above $13 \%$ for levels 4 and 5 . Table 1 gives a summary of system descriptors for both states that will be discussed further below. The net impact analysis sensu Libralato et al. (2006) for both system states is shown in Fig. 4, revealing the positive impact of primary producers during both states and the great increase in negative impact during the El Niño state of the predator groups sharks, barracudas, and benthic predatory fish, but also of the groups sea stars and urchins. The impact of predatory mammals changes from strongly negative during the reference state to strongly positive during the El Niño state.

\section{System response to El Niño reduced primary production}

Fig. 5 shows the satellite-derived time series of chl $a$ and SST used for the construction of the chl $a$ time series for the period 1994 to 2009 and gives the regression equation using both variables.

Phytoplankton biomass was above average during the years preceding the El Niño (predicted based on colder average temperatures for that period), greatly decreased for the El Niño years 1997 and 1998 (by 46 and $33 \%$, respectively), and increased to maximum values over the post El Niño period 1999-2004. Thereafter values decreased and remained below average until the end of the study period.

Fig. 6 shows the observed and simulated trajectories of model group biomasses over the study period forced by the time series of primary producers (phytoplankton and macroalgae). SS between observed and simulated (log) biomasses changed from $\mathrm{SS}=239.5$ (no forcing) to SS $=207$ (forcing using $v=2$ ) and to $\mathrm{SS}=169.5$ (using vulnerability search). Fig. 6 presents only those sensitive groups whose biomass changes over the El Niño cycle were $> \pm 20 \%$ (either in the in situ survey data or as outcome of the simulations). Table 2 provides the results of the fitting for each group separately.

Simulated dynamics of seabirds (penguins and flightless cormorants), mullets, small benthic predatory fishes, and benthic predatory fishes were significantly correlated with observed data. Additional positive correlations exist for surgeonfish, benthic omnivorous groupers, and planktivorous reef fish, although the correlations were not significant at the $p>$ 
0.05 level. A biomass decrease during the El Niño period 1997/98 for the groups sponges and polychaetes,
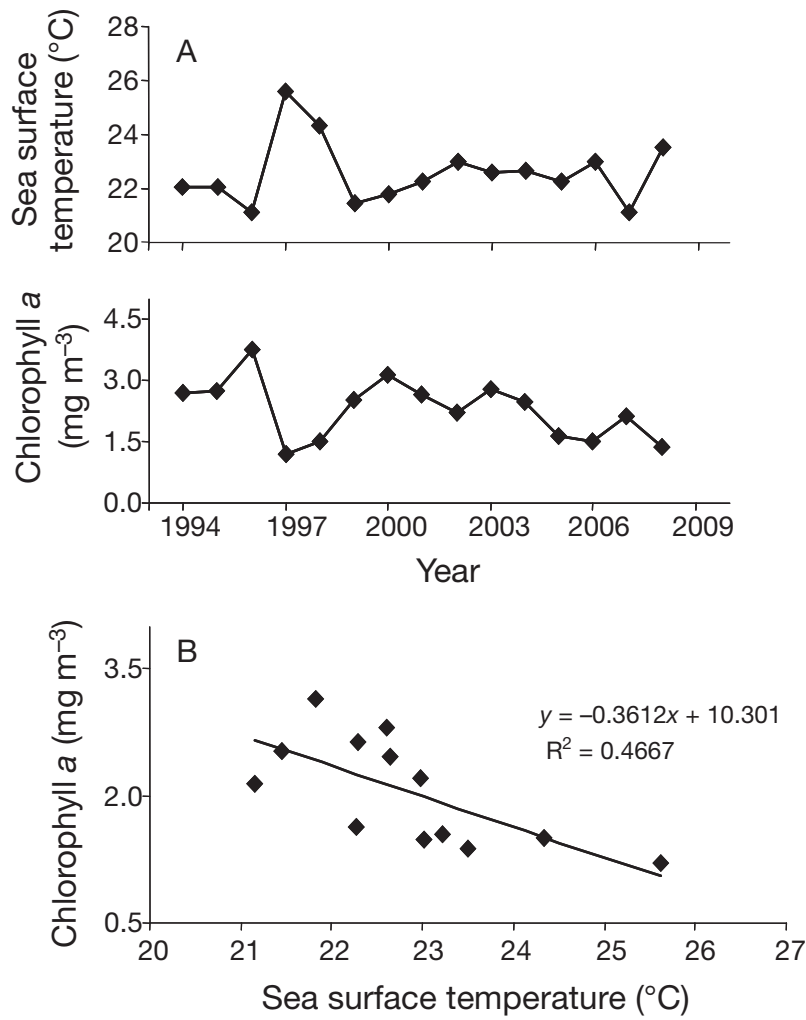

Fig. 5. (A) Annual means of sea surface temperature (SST) and chlorophyll $a$ (chl a) in the Bolivar Channel area and (B) regression between both variables; the chl a values for the years 1994-1997 were approximated by this regression and SST data for these years and jacks and mackerels also correlated significantly to the observed data and was also evident (but not statistically significant) for the groups parrotfish and barracudas, as seen by both simulation and observational data. The groups sea turtles and marine iguanas, and predatory marine mammals decrease only very slightly in the simulations (however, statistically significant in the first case), whereas great density reductions were observed in the field surveys. While post-El Niño population counts remain relatively high in the case of the turtles and iguanas, marine mammal populations vary greatly between annual surveys. The observed stock proliferation of lobster following the El Niño event is also simulated by the model, which provides a statistically significant correlation between observed and simulated values. Since small planktivorous fish were not surveyed quantitatively, their in situ abundance could not be compared with the model simulations, which suggest strong decreases during the El Niño period.

Table S2 in the supplement at www.int-res.com/ articles/suppl/m448p007_supp.pdf shows ranges of the vulnerability values computed for the preypredator matrix during the vulnerability search. While for the groups benthic predatory fish, groupers, small predatory gastropods, jacks and mackerels, and sharks, high vulnerability values of $v>2.0$ point to their role as top-down controllers in the system, the low values of $v=1.0$ for the groups phytoplankton, macroalgae and others, and herbivorous zooplankton suggest bottom-up control of these groups of their consumers.

Table 2. Correlation of observed vs. simulated (log) biomass time series for each model functional group. na: not applicable, no decrease in sum of squares (SS); $\mathrm{r}=$ correlation coefficient; $t=$ Student's $t$ value; $\mathrm{p}=$ significance level

\begin{tabular}{|lcccc|}
\hline Functional group & \% decrease in SS & $\mathrm{r}$ & $t$ & $\mathrm{p}$ \\
\hline Lobsters & 48.00 & 0.465 & 2.280 & 0.038 \\
Sponges and polychaetes & 30.03 & 0.287 & 2.100 & 0.030 \\
Sea turtles and marine iguanas & 25.30 & 0.436 & 2.480 & 0.019 \\
Small benthic predatory fish & 23.10 & 0.193 & 1.828 & 0.040 \\
Jacks and mackerels & 22.30 & 0.270 & 2.110 & 0.027 \\
Seabirds & 20.10 & 0.206 & 1.833 & 0.043 \\
Benthic predatory fish & 4.35 & 0.147 & 1.550 & 0.070 \\
Mullets & 4.30 & 0.247 & 1.720 & 0.060 \\
Surgeonfish, chubs and giant damselfish & na & & & 16 \\
Sea cucumbers and other & na & & & 16 \\
Parrotfish & na & & & 11 \\
Benthic omnivorous fish & na & & & \\
Sea stars and sea urchins & na & & & \\
Planktivorous reef fish & na & & & \\
Barracudas & na & & & \\
Groupers & na & & & \\
Predatory marine mammals & na & & \\
Sharks & & & \\
\hline
\end{tabular}



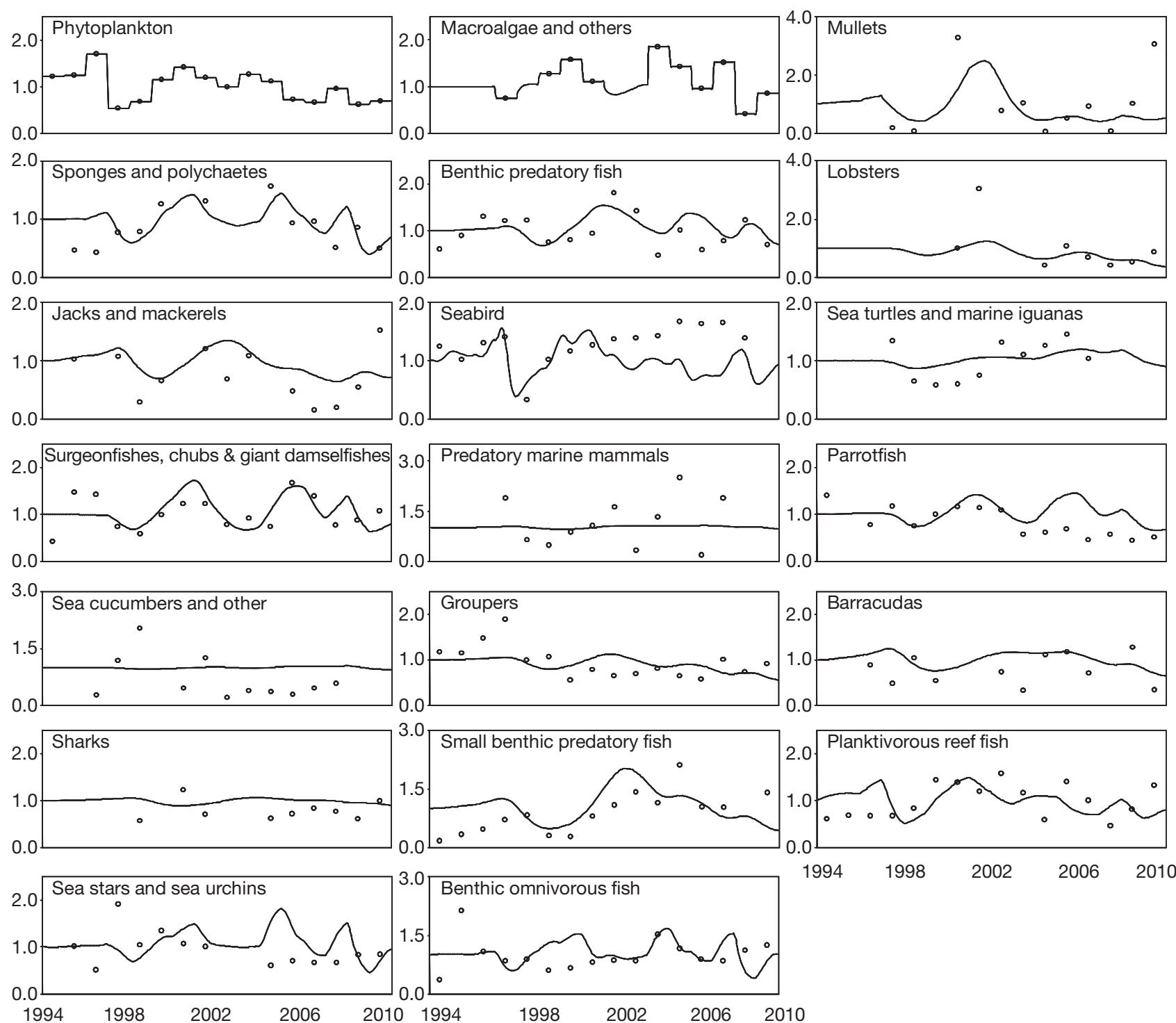

Fig. 6. Simulated (lines) and measured (points) compartment biomasses over the time period 1994 to 2009; vertical axis stands for biomass relative to EwE reference model $(B=1)$; continuous lines represent results following the fitting of vulnerability settings; the model was forced with satellite-derived time series of chlorophyll a biomass and with in situ observations of macroalgae biomass. Through the vulnerability search the sum of squares (SS) between observed and simulated values was reduced from 239.5 to $169.5(-29 \%)$

\section{DISCUSSION}

In the first section we will first discuss the great difference in system characteristics found between the normal and El Niño states of the Bolivar Channel system before putting the system into the regional context by comparing its features with those of other shallow water systems of the eastern Tropical Pacific. In the section that follows, the results of the simulation runs are discussed, as are possible mechanisms behind observed changes of the different groups. In the last section strength and weaknesses of our approach are highlighted.

\section{System characteristics of normal and El Niño states}

As shown by the Lindeman spine (Fig. 3), all trophic levels had largely reduced biomasses during the El Niño event, but it is interesting that the decrease was lowest for the levels II and III (11\%). This can be explained by the fact that several of the 


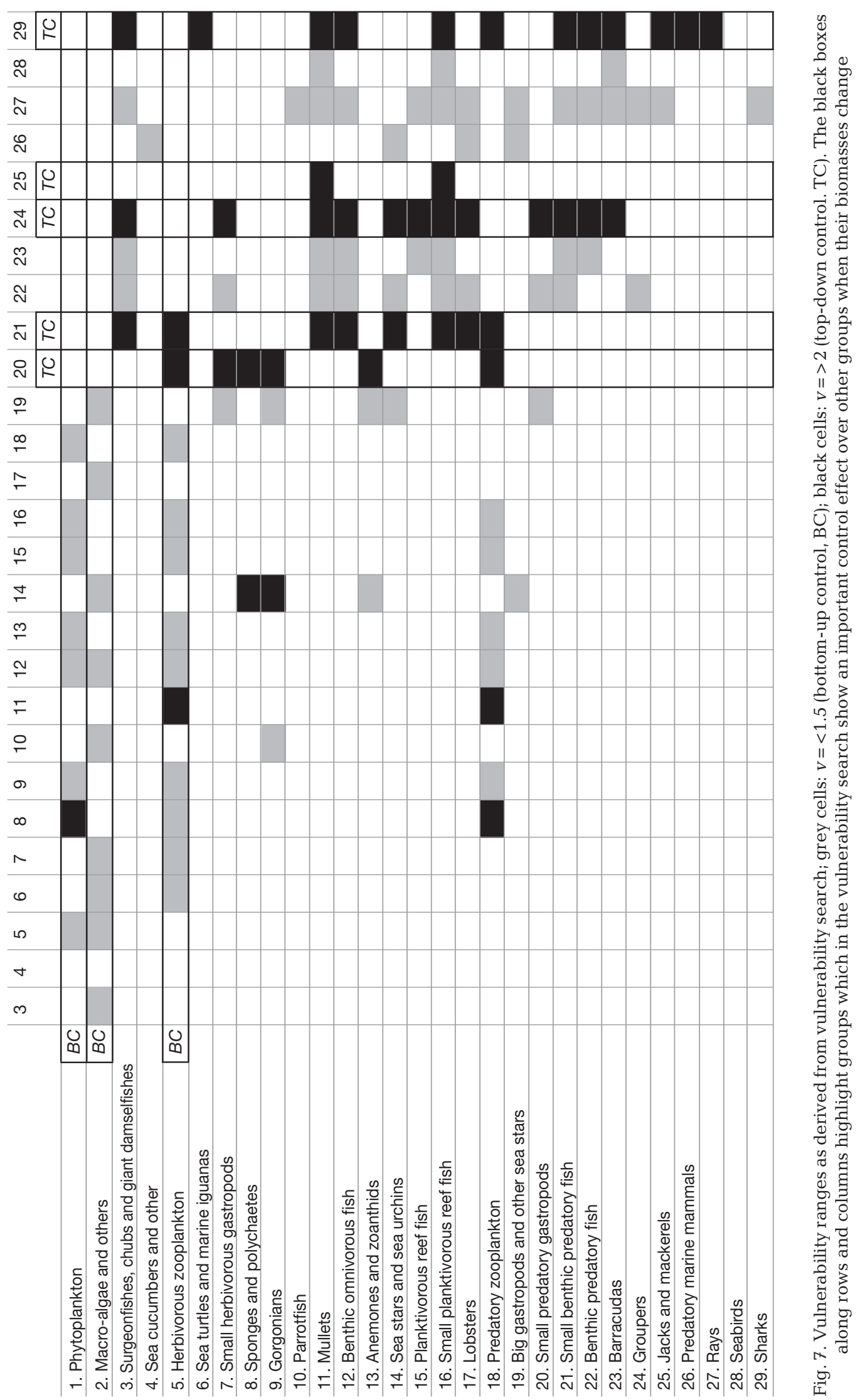


groups on these 2 levels (sea cucumbers and others, sea stars and sea urchins, and big gastropods and other sea stars) use detritus as an important food source, which means that they were not as affected by the El Niño-induced reduction in phytoplankton and macroalgae. As expected, the highest reduction in energy flow occurred between the primary producers and the primary consumers (trophic levels I to $\mathrm{II}_{\text {; }}$ about $88 \%$ ), but the decrease cascades through all trophic levels showing the profound effect of the El Niño on the whole food web.

The net impact analysis (Fig. 4) predicts that the roles (overall system impact) of some of the model groups change during the El Niño state. The most pronounced change is for predatory marine mammals from a strong negative impact during the reference state to a strong positive impact during the El Niño event. This can be explained by the assumed change in diet from several groups of small fish prey (whose biomasses decreased during the El Niño) to large predators such as benthic omnivorous fish, groupers, and sharks (Fig. 7). The great increase in negative impact of sharks during the El Niño state seems to be due to increased proportions of many groups in their diet such as sea turtles, parrotfish, benthic omnivorous fish, planktivorous fish, groupers, and rays, and to the biomass increase of sharks during this period. In general it appears that the relative system impact changes more strongly for predatory groups during the El Niño event, since overall prey biomass decreases and predators make use of any prey they can access, which also implies switching to unusual food items. If, as in the case of sharks and predatory marine mammals, top predators invade the already debilitated system, their impact on the flow structure of the system is thus very strong. The overall positive MTI of mammals during the El Niño state as shown in Fig. 4 seems due to their assumed switch from low trophic level fish species to sharks, groupers, and benthic omnivorous fish, thereby greatly releasing the consumption pressure of these species over their prey.

Overall system biomass as well as energy throughput are reduced to about one-third during the El Niño (Table 1), and explain why catches were also reduced by $55.8 \%$. The parallel increase in the gross efficiency of the catch (catch/primary production) by $100 \%$ can be explained by the fact that the reduction in primary production greatly exceeded the reduction in catch. The reduction of the system $\mathrm{P} / \mathrm{R}$ ratio by $66.4 \%$ is indicative of the relative increase in respiration, since overall production greatly decreased. Finn's cycling index (FCI) increased by $224.8 \%$ dur- ing the El Niño event, showing that a larger fraction of the ecosystem's throughput was recycled, which would, in addition to the reduced P/R ratio, suggest that the system became more mature during the El Niño event. It seems, however, that this value increase can be explained by the very strong reduction in exports (catches) and primary production, which largely reduces the overall throughput and thus inflates FCI. Taylor et al. (2008b) found a similar increase in FCI in the Independencia ecosystem (Peru) during the El Niño state, but showed that FCI decreased below the reference level, when the phytoplankton reduction effect was considered. The lower relative ascendency obtained for the El Niño state can mainly be attributed to the reduction in overall throughput $(T)$ and, possibly to a lesser extent, to the changes in the diet matrix/flow structure of the model. The slight increase of mean transfer efficiency between trophic levels during the El Niño state as well as the great decrease in the system primary production to biomass and system biomass to throughput ratios suggests that energy flow efficiency was improved during the El Niño state. A slightly elevated mean trophic level of the catch during the El Niño state reflects the fact that small planktivorous fish were disproportionally reduced in the catches.

If we compare the Bolivar Channel ecosystem with other tropical shallow water ecosystems, it appears that it has more features of an upwelling system than of a classical tropical system. Its system size (throughput) for non El Niño years of almost $40000 \mathrm{t}$ $\mathrm{km}^{-2} \mathrm{yr}^{-1}$ greatly exceeds tropical systems of the east Pacific seascape region and elsewhere, such as Nicoya Gulf, Costa Rica ( $T=3049 \mathrm{t} \mathrm{km}^{-2} \mathrm{yr}^{-1}$; Wolff et al. 1998), Golfo Dulce, Costa Rica $\left(T=1404 \mathrm{t} \mathrm{km}^{-2}\right.$ $\mathrm{yr}^{-1}$; Wolff et al. 1996), Campeche Bank, Mexico ( $T=$ $2049 \mathrm{t} \mathrm{km}^{-2} \mathrm{yr}^{-1}$; Arreguín-Sánchez et al. 1993), Celestun Lagoon, Mexico $\left(T=8969 \mathrm{t} \mathrm{km}^{-2} \mathrm{yr}^{-1}\right.$; Chavez et al. 1993), South China Sea ( $T=2934 \mathrm{t} \mathrm{km}^{-2}$ $\mathrm{yr}^{-1}$; Silvestre et al. 1993), Venezuelan shelf $(T=7621$ $\mathrm{t} \mathrm{km}^{-2} \mathrm{yr}^{-1}$; Mendoza 1993), Caete Estuary, Brazil ( $T=$ $10559 \mathrm{t} \mathrm{km}^{-2} \mathrm{yr}^{-1}$; Wolff et al. 2000), among others. Instead, it much more resembles coastal ecosystems of the Humboldt current along the Peruvian/Chilean coastline such as Sechura Bay, North Peru $(T=27820$

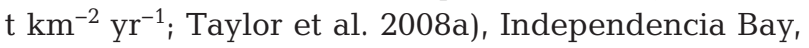
central Peru $\left(T=34208 \mathrm{t} \mathrm{km}^{-2} \mathrm{yr}^{-1}\right.$ vs. $24827 \mathrm{t} \mathrm{km}^{-2}$ $\mathrm{yr}^{-1}$ for normal and El Niño conditions, respectively; Taylor et al. 2008b) or Tongoy Bay, northern Chile ( $T$ $=33579.3 \mathrm{t} \mathrm{km}^{-2} \mathrm{yr}^{-1}$, for sand-gravel habitat; Ortiz \& Wolff 2002). However, in the center of the northern Peruvian upwelling system, throughput is $55689 \mathrm{t}$ 
$\mathrm{km}^{-2} \mathrm{yr}^{-1}$ (Tam et al. 2008), significantly higher than for the above-mentioned coastal systems, including the Bolivar Channel. In this Peruvian system, during the past El Niño event 1997/98, this throughput was reduced by approximately $50 \%$ (Tam et al. 2008), similar to the Bolivar Channel of Galapagos, suggesting that the El Niño impact was very similar between these systems. In this context it is worth noting that the comparison of SST time series between Galapagos and coastal sites of the eastern tropical Pacific also revealed higher similarities between the Galapagos with upwelling sites in Peru than with other tropical sites of the Eastern Tropical Pacific (ETP region) (Wolff 2010).

Maturity as based on the P/R ratio computed (4.20), as well as the relative ascendency (37.4\%), also suggest similarity with a highly productive upwelling system of low to intermediate development, with biomass production exceeding respiration and a rather low complexity of flows. The very low FCI $(1.29 \%)$ is also indicative for a system of little recycling and low development.

One explanation for these system characteristics is the great environmental stochasticity (on inter-annual and intra-annual timescales) to which the Bolivar Channel is subjected. During the 2 strongest El Niño events of the last century, as is shown in the present study, system size was greatly reduced through a bottom-up disruption of the food web, as has also been described for the abovementioned systems of the Peruvian/Chilean coast. The El Niño-Southern oscillation cycle thus seems to periodically 'reset' the system (sensu Bakun \& Weeks 2008) keeping it at a relatively low (but highly productive) development state, also typically for the abovementioned upwelling systems.

On the other hand there are other system features that need to be emphasized. The Bolivar Channel has an enormous diversity and biomass of fish species of different habitats (open water, rocky reef, sand bottom) and trophic guilds (predators, detrivores, planktivores, omnivores), whereas in the coastal upwelling systems of the southeast Pacific, fish diversity is low with a clear dominance of 1 or 2 pelagic planktivores (anchovy and sardine) and just a handful of other, much less abundant, fish species. The Bolivar Channel system also comprises large biomasses of nonbivalve filter feeders (there is, however, a very rare endemic scallop species, Nodipecten magnificus), such as gorgonians Muricea spp. and Pacificgorgia spp., zoanthids Parazoanthus spp., sponges Aplysilla sp. and Carmia sp., and the endemic ahermatypic corals Tubastraea faulkneri and T. tagusensis, while bivalve filter feeders typically dominate the shallow upwelling systems along the southeast Pacific shore. An interesting feature of the Bolivar Channel is the lack of large cangrid or xanthid crabs, well-known benthic predators of the southeast Pacific. Their niche seems to be occupied by 3 species of spiny lobsters (Panulirus penicillatus, P. gracilis, and $P$. femoristruga) and one species of slipper lobster (Scyllaride astori). The proportion of endemic species is high in the Bolivar Channel and exceeds the level of endemism in the northwestern and southwestern regions of Isabela and of western Fernandina. For this reason, and because several invertebrates species have only been recorded here, the Bolivar Channel area is considered unique for its mix of tropical and temperate species (Edgar et al. 2004).

\section{Time series/simulations}

For the fish groups benthic predatory fish, small benthic predators, and mullets, observed reductions in average density following the El Niño event 1997/98 correlated well with those predicted by the model (Table 2), which also predicted observed reductions in surgeonfish (including chubs and giant damselfish), benthic omnivorous fish, and groupers. In case of the Galapagos grouper Mycteroperca olfax, the data suggests that densities were quite high in 1997 and decreased later during El Niño. This is congruent with high catches of this species during the first months of the event, before they dropped. According to Nicolaides et al. (2002), the Galapagos grouper and several other benthic fish (including serranids such as camotillo Paralabrax albomaculatus and norteño Epinephelus cifuentesi) may have migrated to deeper and colder waters during the event and returned when conditions normalized. If this were the case, the model prediction of increased mortalities due to food shortage of these fish during the El Niño event would not mirror reality. Stein-Grove (1985) lists the Galapagos grouper and the camotillo among those fish species that were observed less frequently during scuba dives during the El Niño 1982/83. He also reports a density reduction in the plankton feeding damselfish Chromis atrilobata and Azurina sp., as well as for Labrisomidae in the algaefeeding parrotfish Nicholsina denticulate, which confirms our findings for the El Niño 1997/98. Our survey data for open water predatory fish groups suggest a certain biomass decrease for barracudas and jacks during the El Niño 1997/98, while according to in situ observations, sharks appeared to have increased during the same period. The simulations confirm the 
negative trends for the predatory pelagic fish (statistically significant for jacks and mackerels), while for sharks a rather neutral population response is predicted. Landings of some species of the group jacks and mackerels were lower during and immediately after the El Niño 1997/98 (e.g. sierra Scomberomorus sierra), which would confirm the survey data, while others, like that of wahoo Acanthocybium solandri and palometa Seriola rivoliana, greatly increased (Nicolaides et al. 2002). These latter 2 species are large, open-water species, however, and were not included as part of this model. There is no other available information on the shark response to the El Niño warming. If the survey data reflect reality, the model prediction of a neutral or slightly negative response would be wrong. An explanation could be that sharks successfully switch between prey when the food spectrum changes during El Niño conditions. It could also be that shark onshore movements into the Bolivar Channel area increased during the El Niño period, when open-water resources are reduced, to make use of the different coastal and more easily accessible prey. In this context it seems important to note that the Bolivar Channel area has, on average, a 5 -fold higher phytoplankton biomass than the Galapagos Marine Reserve (GMR) as a whole, and that even during the El Niño period 1997/98 chl a values in the Bolivar Channel area never dropped below levels of average chl a for the greater GMR (approx. $0.4 \mathrm{mg} \mathrm{m}^{-3}$ ), while they were near zero in the GMR (ESA Globcolour database at http://hermes.acri.fr/). These data thus suggest that the Bolivar Channel ecosystem may still be used by the large predators to search for food during this critical period, so that relative shark abundances may have increased in this area as revealed by the survey data.

The seabirds (penguins and flightless cormorants) monitoring data show great reductions in population numbers during the El Niño event 1997/98. ValleCastillo (1985) also reports decreases of 45 and $78 \%$ for cormorants and penguins, respectively during the El Niño 1982/83, with similar reductions recorded during the El Niño in 1997/98 (Vargas et al. 2006). The model simulations confirm the direction and also the magnitude of change (Table 2), which strongly suggests that El Niño-induced food shortage was the main reason for the increased mortalities within both populations, as has been hypothesized before (ValleCastillo 1985, Vargas et al. 2006). Possible reasons for the much higher observed than simulated seabird biomasses for the last decade following the El Niño event are not clear. However, since this decade is considered an extended period of strong upwelling in the study area (Wolff 2010), it is possible that small pelagic fish (including those outside the Bolivar channel) were abundant and contributed to the population increase in sea birds. Sea turtle and marine iguana populations decreased during the El Niño 1997/98, as clearly revealed by the Charles Darwin Foundation monitoring data and also, but to a lesser extent, predicted by our model simulations (Table 2). A similar decrease was reported for the El Niño 1982/83 by Laurie (1985), who attributed it to the great reduction of macroalgae, which forms the basis of their diet. The much larger observed decrease in reptile biomass (as compared to the simulation) may be explained by additional food competition effects with other herbivores under conditions of macroalgae shortage. It appears that the foraging arena for marine iguanas is limited to close-shore algae beds, which require little swimming effort. If algae cover decreases and algae become more patchily distributed, swimming capacity may not suffice for successful feeding under these conditions.

The marine mammals monitoring time series, which shows a significant decrease during the El Niño event (by as much as $50 \%$; Salazar 2002, 2003), is not congruent with the model simulation, which predicts $<10 \%$ population decrease. Possible explanations may be that: (1) The data we used for the time series were extrapolated from surveys conducted in the central and southern areas of Galapagos and did not include the Bolivar Channel area. These other areas may have experienced higher impacts from the El Niño, and thus the extrapolation of their population dynamics may overestimate the reduction in the Bolivar Channel; (2) Our diet matrix for marine mammals considers that only about $30 \%$ of ingested food stems from small pelagic and plankton feeding fish groups, so that food reduction due to the El Niño changes is quite small; and (3) The biomass of marine mammals in our model (and thus the amount of food ingested) is comparatively low at $1 \mathrm{~g} \mathrm{~m}^{-2}$.

For most invertebrate groups, the model simulation predicts substantial population reductions during the El Niño period, but since biomass time series were only available for the groups sea stars and sea urchins, sponges and polychaetes, and lobsters, a comparison between simulated and observed trends can only be done for those groups. In the case of the groups sea stars and sea urchins and of sponges and polychaetes a decrease is seen from 1997 to 1998, as also predicted by the model. The simulation suggests an increase in lobster biomass following the El Niño impact. This trend is even more pronounced in the survey data (Fig. 6) and also confirmed by the fish- 
eries catches, which increased during the post El Niño years 1999 and 2000 (Toral et al. 2002). An explanation for the lobster proliferation following the El Niño event could be the relative low levels of predator (predatory marine mammals and large benthic predatory fish) and high levels of prey (sea urchins, sponges, etc.) biomasses immediately after the event, favoring population increase of the lobsters. The very high biomass value found during the monitoring in 2001 (see Fig. 6), which surpasses the prediction of the model, may have resulted from El Niño (warm water) induced high recruitment levels. This was also reflected in high lobster catches during the year 2001.

The fitting of the time series data based on the model forcing using the phytoplankton and macroalgae time series allowed for a $29.2 \%$ reduction in the sum of squares (from 239.5 to 169.5), which is a substantial improvement in the fit of the curves to the data and clearly shows the importance of the bottomup regulation of the system during El Niño periods. While the observed and simulated biomass trends of the different model groups agreed well in most cases, a statistically significant correlation was only obtained for some groups (Table 2), for which the abovementioned regulatory mechanisms are postulated. Longer observational time series will thus be needed to redo the model simulations and to find out if the observed biomass trends for the other groups also resulted from the postulated mechanisms.

The vulnerability values computed by the program during the search procedure yielded $v$ values indicative of top-down control of their prey (benthic predatory fish, groupers, small predatory gastropods, jacks and mackerel, and sharks), The very low $v$ values of lower trophic levels (phytoplankton, macroalgae, and herbivorous zooplankton) point to their role as bottom-up controllers to higher predators. While most of the $v$ values calculated make ecological sense, a note of caution is needed here, since our time series are relatively short (16 yr) and assembled from different sources, which may limit their value for the vulnerability search routine of EwE.

\section{Strength and weaknesses of approach}

The approach used in the present study is based on several assumptions, and has limitations. As for all ecosystem system scale models, many biota had to be lumped into manageable functional units such as marine iguanas and sea turtles or different species of seabirds and fish. This simplification means a loss in realism, since none of the species lumped together can be considered as having an identical (redundant) function in the system. However, the species grouped in our functional compartments have similar population dynamics, preys, and predators and can be expected to respond in a similar way to disturbances such as El Niño-caused shortage in food and changes in predator abundance. The coupling of our model to time series of environmental drivers and observational data offered a great opportunity to explore the model's capacity to reproduce observed trends. We think that the exercise here presented was worthwhile and shines new light on the trophic functioning of this unique marine ecosystem and the role of $\mathrm{El}$ Niño in shaping the system configuration and modulating the system's bottom-up and top-down regulation over time.

The trophic modeling approach allowed for system scale comparisons with other shallow water areas of the ETP region, revealing that the Bolivar Channel system, although often considered a typical tropical rocky reef system, exhibits many features of an upwelling system of the Humboldt current, despite a unique species composition and high degree of endemism.

The simulation exercise, while revealing that the cascading effect of El Niño reduced primary productivity through the food web, also evidenced that some model groups did not respond as anticipated by the observational data. This is no surprise, since other drivers not captured by our model may play important roles in the regulation of population sizes over time. Examples include lobsters and sea cucumbers, whose proliferation during and shortly after the El Niño period may have been possibly due to El Niñotriggered recruitment events. It may also be assumed that food shortage has not played a crucial role in their population survival during the El Niño warming, since populations of both species have greatly been reduced by the fishery over the past decades, so that food may not even be a limiting factor under conditions of reduced food supply during the El Niño. It seems advisable to combine this kind of ecosystemscale trophic modeling with population scale models in order to better understand the role of different factors in regulating population sizes.

Does the data quality allow for the construction of such a complex trophic model as the one presented here? If we rank our pedigree index (Christensen \& Walters 2004) of the input data (0.54 with a measure of fit of 3.34) with that of other published models (Arreguín-Sánchez et al. 2004, Coll et al. 2006, Morissette 2006, Taylor et al. 2008a), our model can 
be considered of intermediate data quality. The additional use of the resampling routine of EwE (ECORANGER) provided new parameter value estimates that were very similar to the original input values $(<5 \%$ in most cases), indicating that our basic input was very reasonable. However, the fact that the model is balanced thermodynamically and physiologically plausible (parameter ranges are realistic) does not necessarily mean that all input values used are correct.

However, considering that the system modeled is that of a remote archipelago in the tropics, where international research and monitoring standards are difficult to achieve, the data volume and quality is quite astonishing. This holds especially for the long time series of in situ observations of compartment biomasses used for the model construction and time series simulations. We had to make assumptions with regard to the exploitation rate of the fishing targets and had to adjust the diet matrix of the El Niño state to drastic changes in producers and consumers caused by this warming event. While we achieved a mass balanced El Niño model that conforms to the general rules of physiology and trophodynamics of its groups, we cannot exclude the possibility of some biased model inputs. However, the general system properties described and trends observed should be real and meaningful and provide an important basis for future studies.

Acknowledgements. We thank the Galapagos Conservation Trust and the Charles Darwin Foundation for financing this study. Our thanks also go to all scientists that were involved in the marine surveys, which yielded the data set used in this study.

\section{LITERATURE CITED}

Arias-González JE, Delesalle B, Salvat B, Galzin R (1997) Trophic functioning of the Tiahura reef sector, Moorea Island, French Polynesia. Coral Reefs 16:231-246

Arreguín-Sánchez F, Seijo JC, Valero-Pacheco E (1993) An application of ECOPATH II to the north continental shelf of Yuacatan, Mexico. In: Christensen V, Pauly D (eds) Trophic models of aquatic ecosystems. ICLARM Conference Proceedings 26:269-278

> Arreguín-Sánchez F, Hernández-Herrera A, RamírezRodríguez M, Pérez-España H (2004) Optimal management scenarios for the artisanal fisheries in the ecosystem of La Paz Bay, Baja California Sur, Mexico. Ecol Modell 172:373-382

- Ayling AM (1981) The role of biological disturbance in temperate subtidal encrusting communities. Ecology 62: 830-847

Baird D, Ulanowicz RE (1993) Comparative study on the trophic structure, cycling and ecosystem properties of four tidal estuaries. Mar Ecol Prog Ser 99:221-237
Bakun A, Weeks SJ (2008) The marine ecosystem off Peru: what are the secrets of its fishery productivity and what might its future hold? Prog Oceanogr 79:290-299

Banks S, Wiedenfeld D, Loose AM (2003) Monitoring of the Galapagos Marine Reserve: an integrated approach. Final Report to the Heinz Sielmann Stiftung. Charles Darwin Foundation, Santa Cruz, Galapagos

Banks S, Vera M, Toscano M, Ruiz D, Tirado N (2006) Monitoreo ecológico de la zona costera para la evaluación de la zonificación provisional consensuada (ZPC). Resumen de actividades octubre 2004-septiembre 2006. Informe de avances para USAID. Fundación Charles Darwin, Santa Cruz, Galápagos

Breen PA, Mann KH (1976) Destructive grazing of kelp by sea urchins in eastern Canada. J Fish Res Board Can 33: 1278-1283

Brown PC, Painting SJ, Cochrane KL (1991) Estimates of phytoplankton and bacterial biomass production in the northern and southern Benguela ecosystems. S Afr J Mar Sci 11:537-564

Brush MJ, Brawley JW, Nixon SW, Kremer JN (2002) Modeling phytoplankton production: problems with the Eppley curve and an empirical alternative. Mar Ecol Prog Ser 238:31-45

Chavez EA, Garduño M, Arreguin-Sánchez F (1993) Trophic dynamic structure of Celestun Lagoon, southern Gulf of Mexico. In: Christensen V, Pauly D (eds) Trophic models of aquatic ecosystems. ICLARM Conference Proceedings 26:186-192

Chavez FP, Strutton PG, Friederich GE, Felly RA, Feldman GC, Foley DG, McPhaden MJ (1999) Biological and chemical response of the Equatorial Pacific Ocean to the 1997-98 El Niño. Science 286:2126-2131

Christensen V, Walters C (2004) Ecopath with Ecosim: methods, capabilities and limitations. Ecol Modell 172: 109-139

Christensen V, Walters JC, Pauly D (2000) Ecopath with Ecosim, ver. 4. Help system $\odot$. www.ecopath.org

Christensen V, Walters C, Pauly D, Forrest R (2008) Ecopath with Ecosim ver. 6. User guide, Lenfest Ocean Futures Project. www.ecopath.org

> Coll M, Santojanni A, Palomera I, Tudela S, Arneri E (2006) An ecological model of the northern and central Adriatic Sea: analysis of ecosystem structure and fishing impacts. J Mar Sys 67:119-154

de Boyer Montégut C, Madec G, Fischer AS, Lazar A, Iudicone D (2004) Mixed layer depth over the global ocean: an examination of profile data and a profile-based climatology. J Geophys Res 109:C12003 doi:10.1029/ 2004JC002378

Eden C, Timmermann A (2004) The influence of the Galápagos Islands on tropical temperatures, currents and the generation of tropical instability waves. Geophys Res Lett 31:L15308

- Edgar GJ, Banks S, Fariña JM, Calvopiña M, Martínez C (2004) Regional biogeography of shallow reef fish and macro-invertebrate communities in the Galapagos archipelago. J Biogeogr 31:1107-1124

Edgar GJ, Banks SA, Bessudo S, Cortés J and others (2011) Variation in reef fish and invertebrate communities with level of protection from fishing across the Eastern Tropical Pacific seascape. Glob Ecol Biogeogr 20:730-743

Enfield DB (2001) Evolution and historical perspective of the 1997-1998 El Niño-Southern Oscillation. Bull Mar Sci 69: $7-25$ 
Feldman GC (1985) Satellites, seabirds and seals. In: Robinson G, del Pino EM (eds) El Niño in the Galápagos Islands: the 1982-1983 event. Charles Darwin Foundation, Quito, p125-130

Feldman GC (1986) Patterns of phytoplankton production around the Galápagos Islands. In: Bowman M, Yentsch C, Peterson W (eds) Tidal mixing and plankton dynamics. Lecture Notes on Coastal and Estuarine Studies 17, Springer, Berlin, p77-106

Glynn PW, Maté JL, Baker AC, Calderón MO (2001) Coral bleaching and mortality in Panamá and Ecuador during the 1997-1998 El Niño-Southern Oscillation event: spatial/temporal patterns and comparisons with the 1982-1983 event. Bull Mar Sci 69:79-109

Himmelman JH, Lavergne Y (1985) Organization of rocky subtidal communities in the St. Lawrence Estuary. Nat Can 112:143-154

Houvenaghel GT (1978) Oceanographic conditions in the Galápagos Archipelago and their relationships with life on the islands. In: Boje R, Tomczak M (eds) Upwelling ecosystems. Springer, Berlin, p 181-200

Jiménez R (2008) Aspectos biológicos de El Niño en el Océano Pacífico Ecuatorial. Universidad de Guayaquil, Facultad de Ciencias Naturales - Centro de Biodiversidad CENBIO, Guayaquil

Kogelschatz J, Solorzano L, Barber R, Mendoza P (1985) Oceanographic conditions in the Galápagos Islands during the 1982/1983 El Niño. In: Robinson G, del Pino EM (eds) El Niño in the Galápagos Islands: 1982-1983 event. Foundation Charles Darwin, Quito, p 91-123

Laurie A (1985) The effects of the 1982-83 El Niño on marine iguanas. In: Robinson G, del Pino EM (eds) El Niño in the Galápagos islands: 1982-1983 event. Foundation Charles Darwin, Quito, p 199-209

Libralato S, Christensen V, Pauly D (2006) A method for identifying keystone species in food web models. Ecol Modell 195:153-171

Lindeman RL (1942) The tropic-dynamic aspects of ecology. Ecology 23:399-418

Mendoza JJ (1993) A preliminary biomass budget for the northeastern Venezuela shelf ecosystem. In: Christensen V, Pauly D (eds) Trophic models of aquatic ecosystems. ICLARM Conference Proceedings 26:285-297

Morissette L (2006) The trophic role of marine mammals in the northern Gulf of St. Lawrence. Mar Mamm Sci 22: 74-103

Nicolaides F, Murillo JC, Toral MV, Reck G (2002) Bacalao. In: Danulat E, Edgar GJ (eds) Reserva Marina de Galápagos: línea base de biodiversidad. Fundación Charles Darwin/Servicio Parque Nacional Galápagos, Santa Cruz, Galápagos 7:146-165

Ortiz M, Wolff M (2002) Spatially explicit trophic modeling of a harvested benthic ecosystem in Tongoy Bay (central northern Chile). Aquat Conserv 12:601-618

Ruiz DJ, Wolff M (2011) The Bolivar Channel ecosystem of the Galapagos Marine Reserve: energy flow structure and role of keystone groups. J Sea Res 66:123-134

Salazar S (2002) Lobo marino y lobo peletero. In: Danulat E, Edgar GJ (eds) Reserva Marina de Galápagos: línea base

Editorial responsibility: Nicholas Tolimieri,

Seattle, Washington, USA de biodiversidad. Fundación Charles Darwin/Servicio Parque Nacional Galápagos, Santa Cruz, Galápagos 15: 267-290

Silvestre G, Selvanathan S, Salleh AHM (1993) Preliminary trophic model of the coastal fisheries resources of Brunei Darussalam, South China Sea. In: Christensen V, Pauly D (eds) Trophic models of aquatic ecosystems. ICLARM Conference Proceedings 26:300-306

Stein-Grove J (1985) Influence of the 1982-83 El Niño event upon the ichthyofauna of the Galapagos Archipelago. In: Robinson G, del Pino EM (eds) El Niño in the Galapagos Islands: 1982-1983 event. Charles Darwin Foundation, Quito, p 191-198

- Tam J, Taylor MH, Blaskowic V, Espinoza P and others (2008) Trophic flows in the northern Humboldt Current ecosystem. I: comparing 1995-96 and 1997-98. Prog Oceanogr 79:352-365

Taylor MH, Wolff M, Vadas F, Yamashiro C (2008a) Trophic and environmental drivers of the Sechura Bay ecosystem (Peru) over an ENSO cycle. Helgol Mar Res 62(suppl 1): 15-32

Taylor MH, Wolff M, Mendo J, Yamashiro C (2008b) Changes in trophic flow structure of the Independence Bay (Peru) over an ENSO cycle. Prog Oceanogr 79:336-351

Toral MV, Espinoza E, Eran A, Martínez C (2002) Langostas espinosas. In: Danulat E, Edgar GJ (eds) Reserva Marina de Galápagos: línea base de biodiversidad. Fundación Charles Darwin/Servicio Parque Nacional Galápagos, Santa Cruz, Galápagos, 10:199-221

> Ulanowicz RE, Kay JJ (1991) A package for the analysis of ecosystem flow networks. Environ Softw 6:131-142

Ulanowicz RE, Puccia CJ (1990) Mixed trophic impacts in ecosystems. Coenoses 5:7-16

Valle-Castillo CA (1985) Alteracion de las poblaciones del cormorán no volador, el pingüino y otras aves marinas en Galápagos por efecto de El Niño $1982-83$ y su subsecuente recuperación. In: Robinson G, del Pino EM (eds) El Niño in the Galápagos islands: 1982-1983 event. Foundation Charles Darwin, Quito, p 245-258

Vargas FH, Harrison S, Rea S, Macdonald DW (2006) Biological effects of El Niño on the Galápagos penguin. Biol Conserv 127:107-114

Wellington GM, Strong AE, Merlen G (2001) Sea surface temperature variation in the Galapagos archipelago: a comparison between AVHRR night-time satellite data and in situ instrumentation (1982-1998). Bull Mar Sci 69: $27-42$

Wolff M (2010) Galapagos does not show recent warming but increased seasonality. Galapagos Research 67:38-44

Wolff M, Hartmann H, Koch V (1996) A pilot trophic model for Golfo Dulce, a fjord-like tropical embayment, Costa Rica. Rev Biol Trop 44:215-231

Wolff M, Koch V, Chavarria JB, Vargas J (1998) A trophic flow model of the Golfo de Nicoya, Costa Rica. Rev Biol Trop 46:63-79

> Wolff M, Koch V, Isaac V (2000) A trophic flow model of the Caeté Mangrove estuary (North Brazil) with considerations for the sustainable use of its resources. Estuar Coast Shelf Sci 50:789-803

Submitted: June 23, 2011; Accepted: December 6, 2011 Proofs received from author(s): February 13, 2012 